\title{
Relationship between Knowledge, Social Support, and Mother's Attitude towards Exclusive Breastfeeding
}

\author{
Ernita Sari ${ }^{1}$, Astika Gita \\ Ningrum $^{2}$, Risa Etika ${ }^{3}$ \\ ${ }^{1,2}$ Midwifery Study Program, \\ Faculty of Medicine, Airlangga \\ University \\ ${ }^{3}$ Department of Pediatrics, \\ Faculty of Medicine, Airlangga \\ University \\ Email: \\ astika.gita.n@fk.unair.ac.id
}

Received : October $4^{\text {nd }} 2021$

Accepted : October $15^{\text {rd }} 2021$

Published : November $27^{\text {th }} 2021$

\begin{abstract}
Mother's milk (ASI) has an important role in the process of child growth and development. In achieving success of exclusive breastfeeding, of course, there are various factors that influence, including the mother's personality (knowledge and attitude) and social support from the mother's environment around. The purpose of this study was to know related between knowledge, social support and mother's attitude towards exclusive breastfeeding. This quantitative research is observational with a cross sectional approach. The total population of breastfeeding mothers in the Ngadiluwih Community Health Center is 250 people and a sample of 154 mothers was taken use a simple random sampling technique. This research held in January-March 2021. The results showed that majority of mothers gave exclusive breastfeeding by $56.5 \%$. In addition, knowledge possessed by mothers about exclusive breastfeeding was mostly good (79.9\%), social support obtained was high $(54.6 \%)$, but the mother's attitude was still negative (73.4\%). Chi square statistical test on the knowledge variable obtained $\mathrm{p}$ value $=0.002$, social support $\mathrm{p}$ value $=0.657$ while attitude variable obtained $p$ value $=0.075$. There is a significant relationship between knowledge toward exclusive breastfeeding.
\end{abstract}

Keywords: Exclusive breastfeeding, knowledge, mother's attitude, social support

Copyright $\odot 2021$ IIK STRADA Indonesia All right reserved.

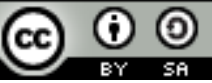

This is an open-acces article distributed under the terms of the Creative Commons AttributionShareAlike 4.0 International License.

\section{INTRODUCTION}

The process of child growth and development is something that parents need to attention, especially in improving nutrition. Fulfillment of balance and quality nutrition will help children to grow and develop optimally. This starts when child is still in the womb until child is born. The government makes a program related to the movement to improve nutrition in the First 1000 Days of Birth (1000 HPK) which consists of 6 indicators, one of which is encouraging exclusive breastfeeding for 6 months (Nefy et al., 2019). In accordance with government regulation Number 33 in 2012 about exclusive breastfeeding, which is give immediately in the first hour of birth until the age of 6 months without given additional food, then breastfeeding will continue until the child is 2 years old with complementary foods (MPASI) (Kemenkes RI, 2018). The World Health Organization (WHO) also recommends same 
thing to give exclusive breastfeeding until age of 6 months and do not give additional food or fluids other except vitamins, minerals or drugs (Wulandari, 2020; WHO, 2019). This is important to get more attention because toddlerhood is a golden period, where $80 \%$ of children's brain growth occurs in this period. Of course this will affect the intelligence of children in the future.

In general, there is a research that middle-income countries are more likely to breastfeed their babies exclusively then high-income countries. This is evidenced by as many as $63 \%$ of infants in high-income countries do not get exclusive breastfeeding (Victora et al., 2016). Besides that, achievement of exclusive breastfeeding at Indonesia in 2019 increased by $67.74 \%$ compared to 2018 which only reached 47\% (Kemenkes RI, 2018, 2020). In addition, East Java Province in 2019 reached 78.3\%, at Kediri Regency was 78.1\% and at Ngadiluwih Health Center reached 77.1\% (Dinkes Kab.Kediri, 2019; Dinkes Provinsi Jatim, 2020). This achievement figure increased from the previous year, but was still less than the program achievement figure targeted by Ministry of Health Republic Indonesia as much as $80 \%$. The level of willingness to breastfeed is high at West Nusa Tenggara Province and only that province is able to achieve the target of exclusive breastfeeding coverage exceeding the national program target of $86.26 \%$ (Kemenkes RI, 2020). This should be a motivation for us who are in other areas to make maximum efforts to support the success of exclusive breastfeeding programs. Not only the government and society will benefit, but children will also benefit in the future.

In the successful of exclusive breastfeeding practice, there are many factors that influence including maternal and infant factors as well as maternal environmental factors. Maternal factors can be physical or psychological, namely is mother's knowledge and attitude towards exclusive breastfeeding. Meanwhile, environmental factors are influenced by existence of social support for mothers from husbands, families, community leaders and health workers. In a study conducted by Rahmaniah explained that knowledge can change mindset of mothers in breastfeeding so will formed positive behavior towards exclusive breastfeeding practice (Rachmaniah, 2014). Another study also stated that higher the social support received, will higher the mother's motivation in giving exclusive breastfeeding (Elsanti and Isnaini, 2018). In addition, other research states that chances of success of exclusive breastfeeding will increase if it is supported by a positive mother's attitude (Arisdiani et al., 2016). Armed with adequate knowledge and experience gained from oneself or others will help shape the mother's attitude towards the breastfeeding process, making it easier for mothers to make decisions to provide nutrition to their babies

Based on the explanation above, the researcher wants to conduct research about relationship between knowledge, social support and mother's attitude with exclusive breastfeeding at working area of the Ngadiluwih Public Health Center, Kediri Regency. It is hoped that this research can help mothers in breastfeeding their babies and encourage achievement of exclusive breastfeeding practice.

\section{MATERIALS AND METHODS}

This research is an observational quantitative research with a cross sectional approach. The population in this study were all 250 breastfeeding mothers and the sample size was 154 use simple random sampling technique. The sample was selected according inclusion criteria determined by the researcher, namely is breastfeeding mothers who have babies aged 6-12 months in good health, both mother and baby, domiciled at work area of the Ngadiluwih Health Center, ready for participate as respondents and have a smartphone for online data collection. This research was held in January until March 2021. There are two variables, namely is independent variable consisting of knowledge, social support and mother's attitude, while dependent variable is exclusive breastfeeding. The instrument used in this study was an online questionnaire in the form of a google form. The questionnaires consisted of a questionnaire about exclusive breastfeeding, a maternal knowledge questionnaire, a social support questionnaire used the Hughes Breestfeeding Support Scale (HBSS), and an attitude questionnaire used the Iowa Infant Feeding Attitude (IIFAS). The questionnaire has been tested for validity and reliability. Furthermore, the researchers distributed questionnaires to respondents online via WhatsApp grub according to the sample size and inclusion criteria that had been determined. The data analysis in this study namely univariate analysis and bivariate analysis. Univariate analysis is used to know the frequency distribution which describes each variable, while bivariate analysis is to determine whether the two variables are related. The process of analyzing the data used chi square statistical test with the help of Microsoft Excel 2013 and SPSS for window version 2.5. This research has received ethical approval from the Health 
Research Ethics Committee, Faculty of Medicine, Airlangga University No. 52/EC/KEPK/FKUA/2021.

\section{RESULTS}

Table 1. Frequency distribution of breastfeeding mothers as respondents

\begin{tabular}{|c|c|c|}
\hline Characteristics & (n) & $(\%)$ \\
\hline \multicolumn{3}{|l|}{ Mother's Age } \\
\hline$<20$ years & 2 & 1,3 \\
\hline $20-35$ years & 135 & 87,7 \\
\hline$>35$ years & 17 & 11 \\
\hline \multicolumn{3}{|l|}{ Mother's Education } \\
\hline Primary School (SD) & 2 & 1,3 \\
\hline Junior High School (SMP) & 30 & 19,5 \\
\hline Senior High School (SMA) & 80 & 51,9 \\
\hline Diploma/Bachelor & 42 & 27,3 \\
\hline \multicolumn{3}{|l|}{ Mother's Job } \\
\hline Does not work/housewife & 109 & 70,8 \\
\hline Government Employees (PNS) & 2 & 1,3 \\
\hline Entrepreneur & 14 & 9,1 \\
\hline Private-Employee & 19 & 12,3 \\
\hline Others & 10 & 6,5 \\
\hline \multicolumn{3}{|l|}{ Family Income } \\
\hline$<1.500 .000$ & 84 & 54,5 \\
\hline $1.500 .000-2.500 .000$ & 50 & 32,5 \\
\hline$>2.500 .000$ & 20 & 13 \\
\hline \multicolumn{3}{|l|}{ Exclusive Breastfeeding } \\
\hline Yes & 87 & 56,5 \\
\hline $\begin{array}{l}\text { res } \\
\text { No }\end{array}$ & 67 & 43,5 \\
\hline
\end{tabular}

Table 1 shows data about characteristics of respondents including mother's age, mother's education, mother's job, family income from 154 respondents. It was found that $87.7 \%$ of respondents were of reproductive age, i.e. $20-35$ years, $51.9 \%$ of the last education was senior high school, $70.8 \%$ of mothers did not work or as housewives, and $54.5 \%$ of family incomes were still below IDR $1,500,000.00$. All respondents adhere to Islam. In addition, respondents who exclusively breastfeed to their babies were $56.5 \%$.

Table 2. Chi Square Test of Knowledge toward Exclusive Breastfeeding

\begin{tabular}{|c|c|c|c|c|c|c|c|c|}
\hline \multirow{3}{*}{\multicolumn{2}{|c|}{ Variable }} & \multicolumn{4}{|c|}{ Exclusive Breastfeeding } & \multirow{2}{*}{\multicolumn{2}{|c|}{ Sum }} & \multirow{3}{*}{$\begin{array}{c}\mathbf{P} \\
\text { Value }\end{array}$} \\
\hline & & \multicolumn{2}{|c|}{ Yes } & \multicolumn{2}{|c|}{ No } & & & \\
\hline & & $\mathrm{n}$ & $\%$ & $\mathrm{n}$ & $\%$ & $\mathrm{n}$ & $\%$ & \\
\hline \multirow[t]{3}{*}{ Knowledge } & Good & 77 & 62,6 & 46 & 37,4 & 123 & 100 & \multirow{4}{*}{0,002} \\
\hline & Sufficient & 10 & 32,3 & 21 & 67,7 & 31 & 100 & \\
\hline & Less & 0 & 0 & 0 & 0 & 0 & 0 & \\
\hline Sum & & 87 & & 67 & & 154 & & \\
\hline
\end{tabular}

Table 2 shows data that more mothers have good knowledge as many as 123 people (79.9\%), only a few mothers with sufficient knowledge as many as 31 people $(20.1 \%)$, even mothers with less knowledge are not found. This means that majority of mothers already know and understand about exclusive breastfeeding. The results of the chi square statistical test show $p$ value $=0.002$, where $p$ value $<0.05$, indicating that knowledge has a meaningful relate toward exclusive breastfeeding. 
Table 3. Chi Square Test of Social Support toward Exclusive Breastfeeding

\begin{tabular}{|c|c|c|c|c|c|c|c|c|}
\hline \multirow{3}{*}{\multicolumn{2}{|c|}{ Variable }} & \multicolumn{4}{|c|}{ Exclusive Breastfeeding } & \multirow{2}{*}{\multicolumn{2}{|c|}{ Sum }} & \multirow{3}{*}{$\begin{array}{c}\mathbf{P} \\
\text { Value }\end{array}$} \\
\hline & & \multicolumn{2}{|c|}{ Yes } & \multicolumn{2}{|c|}{ No } & & & \\
\hline & & $\mathrm{n}$ & $\%$ & $\mathrm{n}$ & $\%$ & $\mathrm{n}$ & \multirow{2}{*}{$\frac{\%}{100}$} & \\
\hline Social & High & 48 & 57,1 & 36 & 42,9 & 84 & & \\
\hline \multirow[t]{2}{*}{ Support } & Sufficient & 38 & 55,1 & 31 & 44,9 & 69 & 100 & 0,657 \\
\hline & Low & 1 & 100 & 0 & 0 & 1 & 100 & \\
\hline \multicolumn{2}{|c|}{ Sum } & 87 & & 67 & & 154 & & \\
\hline
\end{tabular}

Table 3 shows the results of the level of social support which is divided into 3 categories that is high, sufficient and low. Majority of the respondents had a high level of social support as many as 84 people (54.6\%), sufficient social support 69 people (44.8\%) and only 1 person with low social support. Even with high or sufficient social support, it does not guarantee that all respondents will give exclusive breastfeeding. The Chi-square statistical test show $\mathrm{p}$ value $=0.657(\mathrm{p}>0.005)$ which indicates that social support has no effect on exclusive breastfeeding.

Table 4. Chi Square Test of Mother's Attitude toward Exclusive Breastfeeding

\begin{tabular}{cccccccccc}
\hline \multirow{2}{*}{ Variable } & \multicolumn{4}{c}{ Exclusive Breastfeeding } & \multicolumn{2}{c}{ Sum } & \multirow{2}{*}{ P } \\
\cline { 3 - 8 } & & \multicolumn{3}{c}{ Yes } & \multicolumn{2}{c}{ No } & & & Value \\
\cline { 2 - 8 } & & $\mathrm{n}$ & $\%$ & $\mathrm{n}$ & $\%$ & $\mathrm{n}$ & $\%$ & \\
\hline Mother's & Positive & 28 & 68,3 & 13 & 31,7 & 41 & 100 & \multirow{2}{*}{0,075} \\
Attitude & Negative & 59 & 52,2 & 54 & 47,8 & 113 & 100 & \\
\hline Sum & & 87 & & 67 & & 154 & & \\
\hline
\end{tabular}

In table 4 can be seen that respondents with a negative attitude towards exclusive breastfeeding (73.4\%) more than positive attitudes (26.6\%). Most respondents with a negative attitude do not give exclusive breastfeeding. The Chi-square statistical test show $\mathrm{p}$ value $=0.075(\mathrm{p}>0.005)$ which indicates that mother's attotude has no effect on exclusive breastfeeding.

\section{DISCUSSION}

\section{Relationship Knowledge with Exclusive Breastfeeding}

Knowledge is information that appears when someone sees or finds something new that never been encountered before. This can obtainable through learning process either directly such as counseling activities by health professionals, sharing experiences between individuals in the surrounding environment or indirectly through mass media such as television, internet, brochures. With knowledge as the basis of belief and it can affect the way a person thinks in behaving. A behavior that adheres knowledge will usually be more consistent when compared to behavior that is not supported by knowledge.

This study explains that more mothers have good knowledge and tend to exclusively breastfeed their babies. According to research by Widiyanto, knowledge has influence in exclusive breastfeeding practice (Widiyanto et al., 2012). In addition, there is another study which also states that if mother's knowledge about exclusive breastfeeding is minimal, it will have an impact on 1.78 times the mother does not breastfeed her baby exclusively when compared to mothers who are more knowledgeable (Handayani et al., 2016). A better level of mother's knowledge will encourage mothers to have confidence when breastfeeding their babies. So it can be concluded if knowledge contributes to practice of exclusive breastfeeding.

Therefore, there is a need for assistance during pregnancy by health workers to provide valid information about exclusive breastfeeding to build commitment regarding exclusive breastfeeding and attachment to mothers and families and help mothers prepare psychologically to accept new roles when the baby is born. If the mother understands the practice of exclusive breastfeeding well, mother will be more obedient to practice of exclusive breastfeeding. 


\section{Relationship Social Support with Exclusive Breastfeeding}

This study explains that social support is not related toward practice of exclusive breastfeeding. Although majority social support for exclusive breastfeeding is high, this does not strongly influence respondents to carry out exclusive breastfeeding. Based on research results, there were several statements explaining the reason why mothers did not give exclusive breastfeeding because delays in milk production, so mother and family decided to give other foods as additions until the breast milk was smooth. Supported by other findings which state that no significant relate between social support with duration of exclusive breastfeeding (Laugen et al., 2016).

However, it is dissimilar from research by Tawiyah-Agyewang, which social support increases mother's motivation to give exclusive breastfeeding (Tawiah-Agyemang et al., 2008). With strong and trusted social support which includes emotional support, appreciation, instrumental and informational from husbands, families, community leaders and health workers, it can motivate mothers to continue breastfeeding their babies exclusively and reduce the culture of early complementary feeding.

\section{Relationship Mother's Attitude with Exclusive Breastfeeding}

The research shows that most mothers still have a negative attitude towards exclusive breastfeeding, which would make mothers tend not to exclusively breastfeed their babies. Supported by Widiyanto's research which also states that attitude has no influence on the practice of exclusive breastfeeding (Widiyanto et al., 2012). There are several reasons why mothers do not give exclusive breastfeeding, including obstacles when breastfeeding their babies, early complementary feeding when mothers work and lack of mother's knowledge about exclusive breastfeeding. That reasons make mother decide not give exclusive breastfeeding.

Embodiment an attitude does not appear by itself, but there are other things that affect. Knowledge, experience of oneself and others, individual emotional factors, cultural customs or certain people who are considered important and mass media have a role in influencing an individual's attitude. The formation of attitudes is a learning process, which can lead to change. Importance of involvement of health workers in that process, such as promoting good infant visits, early antenatal and postpartum education, and home visits by community health workers, which can help improve knowledge and attitudes of mothers towards breastfeeding practices. Postnatal visits can use as an opportunity by health workers to encourage mothers to seek support during times of difficulty. So professional health care is not just disseminating information, but can overcome obstacles that may prevent mothers from breastfeeding exclusively.

\section{CONCLUSION}

Knowledge has a significant relationship toward exclusive breastfeeding at Ngadiluwih Community Health Center, Kediri Regency. Researchers suggest that families, surrounding communities and health workers can participate in paying attention to nutrition for children, namely by providing support and motivating mothers to remain consistent in exclusive breastfeeding and assisting mothers in digging up information related to exclusive breastfeeding in order to increase mother's knowledge.

\section{ACKNOWLEDGEMENT}

The researcher would like thank to all respondents who have been willing to take a time to participate, as well as all parties who participated in help the smooth running of this research.

\section{REFERENCES}

Arisdiani, T., \& Ph, Livana. (2016). Gambaran Sikap Ibu Dalam Pemberian Asi Eksklusif. Jurnal Keperawatan Jiwa, 4(2), 137-140.

Dinkes Kab.Kediri. (2019). Profil Kesehatan Kabupaten Kediri Tahun 2019. Dinas Kesehatan Kabupaten Kediri.

Dinkes Provinsi Jatim. (2020). Profil Kesehatan Provinsi Jawa Timur Tahun 2019. Dinas Kesehatan Provinsis Jawa Timur.

Elsanti, D., \& Isnaini, O. P. (2018). Hubungan Antara Dukungan Sosial Dan Tingkat Stres Terhadap 
Keberlangsungan Pemberian ASI Ekslusif Di Wilayah Kerja Puskesmas Kedungbanteng. Jurnal Ilmu Keperawatan Maternitas, 1(1), 13. doi.org/10.32584/jikm.v1i1.105

Handayani, L., Yunengsih, Solikhah, \& Saufi, A. (2016). The association between breastfeeding technique and knowledge with exclusive breastfeeding. Jurnal Kedokteran Dan Kesehatan Indonesia, 5(7), 214-218.

Kemenkes RI. (2018). Profil Kesehatan Indonesia Tahun 2018. Kementerian Kesehatan RI.

Kemenkes RI. (2020). Profil Kesehatan Indonesia Tahun 2019. Kementerian Kesehatan RI.

Laugen, C. M., Islam, N., \& Janssen, P. A. (2016). Social Support and Exclusive Breast feeding among Canadian Women. Paediatric and Perinatal Epidemiology, 30(5), 430-438. doi.org/10.1111/ppe.12303

Nefy, N., Lipoeto, N. I., \& Edison, E. (2019). Implementasi Gerakan 1000 Hari Pertama Kehidupan Di Kabupaten Pasaman 2017. Media Gizi Indonesia, 14(2), 186. doi.org/10.20473/mgi.v14i2.186196

Rachmaniah, N. (2014). Hubungan Tingkat Pengetahuan Ibu Tentang ASI Dengan Tindakan ASI Eksklusif. 3-17. doi.org/10.3748/wjg.v13.i15.2209

Tawiah-Agyemang, C., Kirkwood, B. R., Edmond, K., Bazzano, A., \& Hill, Z. (2008). Early initiation of breast-feeding in Ghana: Barriers and facilitators. Journal of Perinatology, 28, S46-S52. doi.org/10.1038/jp.2008.173

Victora, C. G., Bahl, R., Barros, A. J. D. (2016). Breastfeeding in the 21st century: Epidemiology, mechanisms, and lifelong effect. The Lancet, 387(10017), 475-490. doi.org/10.1016/S01406736(15)01024-7

Widiyanto, S., Aviyanti, D., \& Tyas, M. (2012). Hubungan Pendidikan dan Pengetahuan Ibu tentang ASI Eksklusif dengan Sikap terhadap Pemberian ASI Eksklusif. Jurnal Kedokteran Muhammadiyah, 1(2), 25-29. doi.org/10.4039/Ent111111-1

Wulandari, N. furi. (2020). Happy Exclusive Breastfeeding (Pertama). Yogyakarta: Laksana. 